\title{
Tanggung Jawab TNCs Terhadap Pelanggaran Hak Asasi Manusia Dan Lingkungan Dalam Perspektif Hukum Internasional Dan Hukum Hak Asasi Manusia Internasional
}

\section{Sri wartini}

\begin{abstract}
Abstrak
International Human Rights Law and International Environmental Law is not able to protect efectively the violation of human rights and the right of enviromental protection exercised by TNCs, because TNCs is not subject of intemational law. 'The establishing and exercising soft-law such as code of conduct, global compact and OECD guidelines is expected to change the attude of TNCs in the future.
\end{abstract}

$-$

\section{- Pendahuluan}

Kekuatan ekonomi Perusahaan Transnasional (Transnasional Corporations) selanjutnya akan disebut TNCs tidak diragukan lagi. Perusahaan ini merupakan agen penggerak ekonomi global, mereka mengatur dan menguasai perdagangan internasional, investasi dan alih teknologi. ${ }^{1}$ Dampak positif investasi langsung TNCs ke negara-negara berkembang antara lain membuka lapangan kerja, penyediaan modal dan alih teknologi, namun demikian telah banyak juga fakta yang menunjukkan dampak negatif yang dilakukan oleh TNCs seperti pelanggaran hak (abuse of nights), baik itu pelanggaran terhadap hak asasi manusia maupun pelanggaran terhadap perlindungan lingkungan ${ }^{2}$ di beberapa negara berkembang, misalnya, Coca-Cola di Kulumbia dan Phillips-Van Heusen di Guatemala telah terbukti melakukan intimidasi secara sistematis, penyiksaan, penculikan, penahanan dan pembunuhan terhadap karyawan yang dilakukan oleh para militer yang bekerjasama dengan agen perusahaan yang bersangkutan. ${ }^{3}$

${ }^{1}$ David Kinley dan Junko Tadaki, “From Talk to Walk: The Emergence of Human Rights Responsibility for Corporation at untemational Law, (Virginia Joumal of International Law, Summer 2004), him.1.

${ }^{2}$ Alison Lindsay Shinsato, "Increasing The Accountability of Transnational Corporations for Environmen- . tal Harms : The Petrolium Industri in Nigeria", (4 Northwestern University Joumal of Internatioanl Human Rights, December 2005), hlm.1.

${ }^{3}$ David Kinleydain Junko Tadaki, loc.cit. 
Selain itu TNCs yang bergerak dalam bidang pertambangan telah menyebabkan kerusakan lingkungan yang serius dan mengancam hak untuk memperoleh pangan yang cukup, serta hak untuk memperoleh standar hidup yang layak, misal Royal Duch/ Shell's Oil Production di Negeria, dan BHP Billiton's Coper Mining di Papua New Guinea. Kemudian di Equador, TNCs yang melakukan pengeboran minyak mempekerjakan buruh anak serta mencemarkan ekosistem, sehingga membahayakan kesejahteraan penduduk asli yang tergantung pada ekosistem tersebut, ${ }^{4}$ dan satu lagi kasus yang terjadi di Indonesia yang dilakukan oleh PT Freeport McMoran telah melakukan perusakan lingkungan dan pelanggaran hak asasi manusia.

TNCs dapat mengeruk banyak keuntungan di host state dengan adanya standar lingkungan yang rendah, sehingga banyak penduduk yang. menjadi korban akibat kerusakan lingkungan, karena eksploitasi yang dilakukan TNCs di negara berkembang. Sebagian besar TNCs berbasis di-negara maju namun mereka berinvestasi di negara berkembang untuk memperoleh cost effective.

Akan tetapi dalam hukum internasional, TNCs masih sangat jarang sekali diakui sebagai subjek pelanggar hak asasi manusia. TNCs tidak berstatus international legal person. ${ }^{6}$ Oleh karena itu, TNCs tidak memiliki hak dan kewajiban sesuai hukum intemasional, namun dalam hal-hal tertentu perusahaan tersebut dapat membuat persetujuan dengan pemerintah suatu negara dengan memberlakukan prinsip-prinsip hukum internasional atau prinsip-prinsip umum hukum untuk transaksi mereka dan bukan diatur oleh hukum nasional suatu negara. Hal ini sering disebut internationalized contract. ${ }^{\dagger}$

Regim Hukum Hak Asasi Manusia Intemasional tidak secara langsung mengatur kewajiban hukum TNCs. Pandangan ortodok hukum Hak Asasi Manusia hanya mengatur dan mengikat negara, ${ }^{8}$ karena hukum ini sesungguhnya dibuat untuk melindungi hak asassi manusia dari kesewenangan pihak penguasa. Oleh karena itu, jika terjadi pelanggaran hak asasi manusia yang dilakukan oleh kekuasaan privat, maka negara yang bertanggung jawab. Dalam kekosongan hukum internasional inilah TNCs melakukan pelanggaran terhadap hak asasi manusia maupun terhadap perlindungan lingkungan.

Banyaknya kasus-kasus pelanggaran hak asasi manusia maupun pelanggaran terhadap perlindungan lingkungan yang dilakukan TNCs di negara-negara berkembang yang tidak tersentuh hukum baik oleh hukum nasional maupun hukum internasional mendorong penulis untuk menganalisis pelanggaran hak asasi manusia dan pelanggaran perlindungan lingkungan oleh TNCS berdasarkan perspektif Hukum Internasional dan Hukum Hak Asasi Manusia Internasional.

\section{${ }^{4} \mathrm{lbid}$.}

${ }^{5}$ http://id.wikipedia.org/wiki/Freeport_Indonesia. diakses pada tanggal 20 Maret 2006.

${ }^{6}$ Boer. Mauna, Hukum Intemasional Pengertian, Peranan dan Fungsi Dalam Era Dinamika Global, (Bandung, Alumni, 2000), him. 56.

7 lbid.

${ }^{8}$ Martin Dixon, Public Intemational law, Fourth Edition, (United Kingdom, Bkackstone Press Limited), hlm. $325-326$. 


\section{Sejarah Singkat Perkembangan Hak Asasi Manusia}

Sejak Perang Dunia il, kesadaran nilainilai hak asasi manusia telah menjadi kebijaksanaan internasional. Teori tentang hak asasi manusia telah berkembang sejak lama, namun baru pada perang dunia kedua masyarakat internasional menyepakati tentang prinsip-prinsip hak asasi manusia secara universal. ${ }^{9}$ Sehingga perlindungan hak asasi manusia bukanlah merupakan masalah suatu negara secara individual.

Setelah Perang Dunia kedua, pengakuan pertama terhadap prinsip-prinsip hak asasi manusia secara universal ialah-dengan disepakatinya Deklarasi Hak Asasi Manusia (Universal Declaration Of Human Rights) selanjutnya akan disebut UDHR yang dibuat oleh PBB. Pada Tahun 1945, semua negara anggota PBB berjanji untuk bekerja sama mengatasi masalah internasional dan salah satunya adalah masalah perlindungan hak asași manusia, maka pada tahun 1948 ditanda tangani Deklarasi Hak Asasi Manusia, sekalipun penandatanganan Deklarasi tersebut tidak mengikat bagi negara penandatangan. ${ }^{10}$ Akan tetapi Deklarasi ini merupakan dasar bagi dokumen-dokumen hak asasi manusia lainnya.

Dua dokumen berikutnya yang memberikan kontribusi penting terhadap hukum Hak Asasi
Manusia Internasional ialah International Covenant on Civil and Political Rights tahun 1966 [selanjutnya akan disebut ICCPR] dan Intermational Covenant on Social And Cultural Rights tahun 1966 [selanjutnya akan disebut/CESCR]. ${ }^{11}$ Dukumen tersebut sebenamya merupakan satu dokumen yang berusaha mentransformasi Deklarasi Hak Asasi Manusia ke dalam suatu hak yang mengikat secara hukum dan membentuk mekanisme beserta institusinya.

-Sejak pembuatan ICCPR dan ICESCR, telah banyak dikeluarkan berbagai macam Konvensi maupun Deklarasi yang berkaitan dengan aspek khusus hak asasi manusia, seperti hak atas penduduk asli (rights indigenous people) $)^{12}$ dan hak anak. Perlindungan hak asasi manusia terhadap kerusakan lingkungan merupakan suatu perkembangan baru dalam masyarakat internasional, walaupun ada suatu hubungan (link) yang signifikan antara hak asasi manusia dan lingkungan. Sejak terbentuknya Deklarasi dan Kovenan dalam Hukum Hak Asasi Manusia, para pembuat draf tidak menyadari akan perlunya pertimbangan dan nilai-nilai hak asasi manusia terhadap kerusakan lingkungan.

\section{Evolusi Hukum Lingkungan Internasional}

Salah satu permasalahan penting yang muncul ialah tentang formulasi hak lingkungan

\footnotetext{
${ }^{9}$ Rhona K.M. Smith, International Human Rights Law, Second Edition, (Oxford University Press, New York, 2005). hlm.5.

${ }^{10}$ Lauren A. Mowery, "Earth Rights, Human Rights: Can Environmental Human Rights Affect Corporate accountability ?", Fordham Environmental Law joumal,Vol.13, Spring, 2002, hlm. 2.

${ }^{11}$ Rhona K.m. Smith, op.cit., hlm.47-49.-

${ }_{12}$ Tracy M. Schmidt, "Transnational Corporate Responsibility for International Environmental And Human Rights Violations: Will the Unitted Nations "Norms "Provide The required Means ?", Califormia Westerm Law Journal, Vol.36, Fall 2005, hlm.2.
} 
tersebut apakah pendekatannya didasarkan pada antropocentris atau pendekatan ekologis. Berdasarkan pandangan Antropocentris memandang manusia sebagai pusat dari sistem alam semesta. Manusia dan kepentingannya dianggap yang paling menentukan dalam tatanan ekosistem dan dalam kebijakan yang diambil dalam kaitannya dengan alam, baik secara langsung maupun tidak langsung. ${ }^{13}$ Lingkungan hanya dipandang sebagai suatu barang atau aspek untuk memenuhi kebutuhan manusia. Sedangkan pendekatan ekologis-memandang lingkungan sebagai bagian dari suatu kehidupan sehingga pemanfaatannya harus ada batasnya. Secara ekologis, makluk hidup dan benda-benda abiotis lainnya saling terkait satu sama lain. Oleh karena itu, kewajiban dan tanggung jäwab moral tidak hanya dibatasi pada makluk hidup. Kewajiban tanggung jawab moral juga berlaku bagi semua realitas ekologi. ${ }^{14}$

Banyak juga para ahli lingkungan yang menggunakan pendekatan antropocentris untuk memformulasikan-hak lingkungan, karena lingkungan dipandang sebagai suatu unsur untuk memenuhi kebutuhan manusia. Akan tetapi pendekatan ini sebetulnya hanya akan bermuara pada pemenuhan kebutuhan manusia dan akhirnya akan berakhir dengan kerusakan lingkungan. Di samping itu, sebenamya perlindungan lingkungan hanyalah sebagai konsekuensi untuk melindungi kehidupan manusia dan standar kesehatan.

Sedangkan kelompok yang tidak sepakat dengan pendekatan antropocentris berargumen bahwa pendekatan antropocentris dapat diterima kalau hanya manusia yang merupakan satusatunya species yang merupakan bagian integral dengan alam itu sendiri. Sehingga, hak asasi manusia dapat berperan untuk melindungi lingkungan sebagaimana perlindungan terhadap kepentingan manusia. ${ }^{15}$

Perkembangan Hak Asasi Manusia terhadap lingkungan. Salah satu indikator penting dalam perkembangan Hukum Hak Asasi Manusia, ialah sampai sejauhmana telah memasukkan Hak Asasi Manusia dalam lingkungan dalam konstitusi negara.-Suatu studi telah menunjukkan bahwa antara 50 sampai dengan 60 konstitusi nasional suatu negara telah mencantumkan hak asasi lingkungan. Lebih lanjut lagi, banyak konstitusi suatu negara yang telah mengadopsi atau melakukan amandemen sejak disepakatinya Stockholm Declaration tahun 1972.

Sebagai salah satu contoh Konstitusi Brasil telah mencantumkan tentang hak setiap orang terhadap keseimbangan ekologi dalam lingkungan, di mana lingkungan merupakan public good bagi semua orang, dan sangat penting untuk kesehatan manusia. Baik pemerintah maupun masyarakat memiliki kewajiban untuk melindungi dan melestarikan lingkungan bagi kepentingan generasi sekarang dan generasi yang akan datang. Demikian juga Portugal Dalam ketentuan Pasal 66 Konstitusinya juga menyatakan bahwa setiap orang memiliki hak untuk menikmati lingkungan yang sehat, keseimbangan lingkungan dan berkewajiban untuk mempertahankannya. ${ }^{16}$

\footnotetext{
${ }^{13}$ A. Sonny Keraf, Etika Lingkungan, Jakarta, Kompas, 2002, hlm. 31.

${ }^{14}$ A. Sonny Keraf, Ibid., hlm.75-76.

${ }^{15}$ L.auren A. Mowery, Ibid., hlm.3.

${ }^{16}$ Lauren A. Mowery, op.cit., hlm.4.
} 
Selain itu di berbagai macam ketentuan regional juga mengakui hak asasi lingkungan, misalnya saja Piagam Afrika Tahun 1981 memuat hak tersebut secara jelas dan ekplisit. Dalam Pasal 24 African Charter menyatakan bahwa : semua orang harus memiliki hak lingkungan yang nyaman dalam rangka pelaksanaan pembangunan. Sedangkan dokumen lain yang juga mengakui hak asasi lingkungan ialah The 1988 Protokol to the American Convention on Human Rights in the Area of Economic, social and Cultural Rights, atau juga dikenal the Salvador Protocol. Dalam Pasal 11nya menyebutkan bahwa : "setiap orang berhak untuk menikmati lingkungan hidup yang sehat dan akses kepada pelayanan publik". ${ }^{17}$

Selain itu, dalam masyarakat Eropa ada sejumlah dokumen yang menekankan dan menyebutkan tentang hak untuk menikmati lingkungan yang sehat. The Organization for Economic Cooperation and Development (OECD) menyatakan bahwa : " fundamental rights should include a right to decent environment "(hak dasar harus meliputi juga hak untuk mewarisi lingkungan). Ketentuan hak lingkungan yang masih berupa Draft termuat dalam The Charter on Environment Rights and Obligations yang dibuat oleh United Nations Commission on Europe (UNECE) yang mendukung hak universal untuk menikmati lingkungan yang sehat dan bertujuan untuk melestarikan. lingkungan bagi generasi sekarang maupun generasi yang akan datang. ${ }^{18}$ Beberapa proposal juga telah dipertimbangkan untuk menambahkan hak lingkungan dalam The European Convention on Human Rights, walaupun belum dilaksanakan.

Pertemuan Menteri Negara Eropa tentang Kesehatan dan Lingkungan yang diselenggarakan di London pada-bulan Juni 1999, ini adalah merupakan pertemuan yang ketiga dan tujuannya adalah untuk menempatkan kesehatan dan lingkungan sebagai salah satu agenda politik. Dalam pertemuan tersebut dihadiri juga oleh unsur organisasi non pemerintah dan berbagai macam sektor pemerintah, pihak-pihak yang berkepentingan dan para pengusaha. Pembangunan berkelanjutan dalam kaitannya dengan lingkungan dan hak asasi manusia menjadi tema utama dalam Konferensi tersebut. Direktor Jenderal WHO pada waktu itu menyatakan bahwa selama kesehatan dipandang sebagai tanggung jawab negara dan bukan juga sebagai pembagian tanggung jawab antara individu, pekerja dan pemilik usaha, maka pembangunan berkelanjutan ${ }^{19}$ hanya akan merupakan tujuan yang mengawang-awang.

Kesepakatan internasional yang juga mengelaborasi hubungan antara pembangunan berkelanjutan dan perlindungan lingkungan antara lain termuat dalam Deklarasi Stockholm, Deklarasi Rio dan Deklarasi Johanesbourg, walaupun Deklarasi-Deklarasi tersebut memuat suatu pesan yang kontradiksi ${ }^{20}$

\section{${ }^{17}$ Ibid.}

${ }^{18}$ Edith Brown Weiss, "Intergenerational Equity :A legal Framework for Global Environmental Change ", dalam Environmental Change and International Law, (United Nations, Tokyo University Press, 1992), hlm 385.

${ }^{19}$ Philippe Sands, Principles of Intemational Environmental Law, (New York, Manchester University Press, 1995), him.198.

${ }^{20}$ Daniel C Esty, Greening the GATT, Trade, Environment, and the Future, (London, Longman Group, UK limited, 1994), hlm. 163-164. 
berkaitan dengan kesehatan, lingkungan dan hak asasi manusia. Deklarasi - deklarasi ini tidak memberikan spesifikasi hak kepada individu untuk menikmati lingkungan yang sehat, tetapi menyatakan bahwa manusia merupakan pusat perhatian pembangunan berkelanjutan, maka manusia berhak untuk menikmati kehidupan yang produktif yang harmonis dengan lingkungan, yang diasosiasikan dalam kebijakan proses pembangunan. ${ }^{21}$

Deklarasi Rio merekomendasikan negara untuk membuat ketentuan hukum nasional yang mengatur tentang pembayaran ganti kerugian yang berkaitan dengan kerusakan lingkungan. Deklarasi ini mirip dengan Deklarasi Stockholm yang juga memberikan ketentuan yang ambigius, disatu sisi negara berhak untuk mengeskploitasi sumber alamnya sesuai dengan kebijakan lingkungannya, ${ }^{22}$ namun disisi lain menyatakan bahwa negara berkewajiban untuk melindungi lingkungan secara luas.

Pembentukan standar hak asasi manusia yang dibuat oleh PBB belum secara langsung mengakui tentang hak asai manusia terhadap lingkungan. ${ }^{23}$ Akan tetapi suatu dokumen tertentu telah membuat suatu hubungan antara lingkungan dan hak asasi manusia, antara lain The United nations on the Rights of the Child secara ekperssif merujuk pada kualitas lingkungan dalam artikel 24 tentang hak untuk sehat. Lagi pula, the Special Rapporteur dari
PBB, Sub Komisi dalam Pencegahan Diskriminasi dan Perlindungan Terhadap Minoritas telah menunjukkan adanya perhatian terhadap perkembangan hak asasi lingkungan. ${ }^{24}$ Walaupun dia tidak membuat suatu draf tentang instrumen baru yang menyertakan hak asasi manusia dalam lingkungan, Rapporter ini telah mendukung evolusi hak tersebut dalam hukum kebiasaan internasional.

Ada dua doktrin dalam hak asasi manusia yang dapat dikembangkan dalam perlindungan korban kerusakan lingkungan. Keberadaan Hukum Hak Asasi Manusia Internasional beserta stuktur hukumnya, maka remidi terhadap kerusakan lingkungan -adalah menghubungkan antara kerusakan lingkungan dengan hak asasi manusia fundamental. Sedangkan dalam pengertian yang luas, yaitu memperluas substansi hak asasi manusia dengan memasukkan hak asasi manusia terhadap lingkungan, seperti misalnya hak terhadap lingkungan yang aman. Berdasarkan perdebatan lama tentang pembentukan hak lingkungan baru, nampaknya hak tersebut akan muncul dimasa yang akan datang. Untuk sementara waktu, mungkin hak asasi lingkungan dapat diinterpretasikan secara luas untuk melindungi hak asasi manúsia.

Mekanisme hak asasi manusia yang telah ada merupakan suatu alat untuk melindungi korban yang diakibatkan oleh kerusakan lingkungan. Seperti misalnya yang

${ }^{21}$ Arjun Sengupta, "Trade and Development Prospect of Developing Countries ", dalam WTO Secretariat, Trade Development and the Environment, (London, Kluwer Law International, 2000), him.219-220.

${ }^{2}$ Nico Schijver, Souveregnty over Naturaral Resources, (Cambridge University Press, New York, 1997), him.124-125.

${ }^{23}$ Alan E. Boyle and Michael R.Anderson, Human Rights Approachs to Environmental Protection, (New York, Oxford University Press, 1996), hlm.7.

${ }^{24}$ Lauren A. Mowery, op. cit., him. 5. 
tercantum dalam. Deklarasi Stockholm maupun deklarasi-Rio, berusaha untuk menghubungkan antara perlindungan lingkungan dengan hak asasi internasional yang telah ada. Misalnya hak untuk hidup, hak kesehatan, dan hak untuk menikmati standar hidup yang memadai adalah merupakan hak dalam hak asasi manusia yang dapat dijadikan sebagai landasan/pijakan untuk tuntutan lingkungan, Misainya, hak untuk hidup adalah berkaitan erat dengan risiko lingkungan yang mengancam kehidupan, merupakan cakupan perlindungan yang dimaksudkan oleh hak untuk hidup.

Beberapa ahli lingkungan aktivis hak asasi manusia sepakat bahwa ada suatu hubungan standar antara lingkungan dan hak asasi manusia. Walaupun argumen yang progressif-berpendapat bahwa hukum kebiasaan internasional telah mengakui hak asasi manusia untuk mewarisi lingkungan yang sehat dan berkelanjutan. ${ }^{25}$ Menurut pandangan ini hukum internasional seharusnya memberikan pengakuan secara ekplisit, namun permasalahannya ialah bagaimana mendefinisikan-ruang lingkup hak tersebut.

Komite Hak Asasi Manusia (The Human Rights Committee) berpendapat bahwa hak untuk hidup yang dimuat dalam Kovenan mewajibkan negara melakukan tindakan tindakan tertentu untuk mengurangi kematian bayi dan memperpanjang kesempatan hidup. ${ }^{26}$ Berarti ini menunjukkan adanya suatu hubungan yang erat antara kewajiban.negara untuk melindungi lingkungan dan untuk menjamin hak unuk hidup, karena kalau lingkungan tidak dilindungi, misalnya dibiarkan tercemar atau rusak akan mengakibatkan berkurangnya kesempatan untuk hidup, dengan kata lain hak untuk hidup ini terkurangi karena kondisi lingkungan yang buruk.

\section{Perusahaan Transnasional dan Hukum Hak Asasi Manusia Internasional}

Tanggung Jawab Perusahaan Transnasional di tingkat internasional, terutama berdasarkan hukum Hak Asasi Manusia International telah muncul dari dua hal. Pertama, fakta historis bahwa hukum hak asasi manusia dibuat sebagai alat untuk melindungi individu dari kekuasaan negara yang sewenag-wenang, dan bukan dari kekuasaan perusahaan kekuasaan badanbadan swasta lainnya. ${ }^{27}$ Karena TNCs tidak termasuk subyek yang diatur oleh Hukum Hak Asasi Manusia, maka tanggung jawab perusahaan tersebut secara tidak langsung menjadi tanggung jawab negara. Secara tipikal, hal tersebut diatur dalam suatu perjanjian internasional yang membebankan kewajiban dan hak kepada negara. ${ }^{28}$

Dalam tingkat nasional, pelaksanaan hukum hak asasi manusia selain mengatur tindakan negara yang secara potensial dapat melakukan pelanggaran hak asasi manusia

${ }^{25} \mathrm{http}: / /$ www unhcr.ch/business.htm, diakses tanggal 20 Maret 2006. United Nations High Commissioner for Human Rights, Business And Human Rights : AProgress Report ( Jan. 2000)

${ }^{26}$ Alan E. Boyle and Michael R.Anderson, op.cit, hlm.90.

${ }^{27}$ MichaelAkehurst, AModern Introduction to Intemational Law, fourth Edition, (London, GeorgeAllen and UNWIn limited, 1982), hlm.76-77.

${ }^{28}$ David Kinley dan Junko Tadaki, op.cit., Him. 5. 
(vertical application) jüga mengatur pelanggaran hak asasi manusia antara individu dengan individu atau dengan badan hukum (horizontal application). Jika penggunaan hukum hak asasi manusia yang secara horizontal ini diberlakükan juga terhadap perilaku TNCs maka akan membawa kepada alasan yang kedua, yaitu hukum perusahaan secara tradisional adalah merupakan urusan nasional. Tanggung jawab hak asasi manusia tidak diatur dalam hukum hak asasi manusia tetapi misalnya diatur dalam hukum perusahaan itu sendiri seperti anti-diskriminasi, kesehatan dan keselamatan kerja, dan hukum perburuhan.

Hukum Hak Asasi Manusia hanya didesain untuk diberlakukan dalam lingkup nasional saja. Sebagai akibatnya, pelanggaran hak asasi manusia TNCs yang beroperasi di wilayah negara lain tidak tersentuh oleh hukum nasional negaranya dan karena TNCs juga bukan subjek hukum internasional maka TNCs juga tidak tersentuh oleh hukum internasional. Tentu saja secara teoritis hukum nasional host state memungkinkan untuk diterapkan. Namun demikian, di banyak negara terutama negara berkembang, -ketentuan seperti itu biasanya merupakan kompromi antara negara berkembang dengan perusahaan Transnasional yang disebabkan oleh kedudukan yang tidak seimbang. ${ }^{29}$

\section{a. Status PerusahaanTransnasional dalam Hukum Internasional}

Secara tradisional perusahaan Transnasional tidak diakuai sebagai subyek hukum internasional. Sehingga untuk memberlakukan ketentuan hukum internasional terhadap perusahaan Transnasional merupakan suatu revolusi, karena berdasarkan hukum intemasional TNCs ini hanya merupakan obyek hukum internasional. Oleh karena itu, sebelum kewajiban hukum hak asasi manusia dapat diterapkan kepada TNCs, maka TNCs harus diakui dulu sebagai subjek hukum internasional, atau setidaknya sebagai partisipan dalam hukum internasional yang mampu melaksanakan kewajiban internasional.

Dengan kata lain TNCs harus memiliki personalitas hukum (legal Personality). ${ }^{30}$ Sejak berakhirnya Perang Dunia kedua hukum internasional telah mengakui beberapa subjek hukum lain yang mereka itu bukan negara, seperti misalnya dalam kasus Reparation Case, juga diakuinya individu sebagai subyek hukum internasional. Oleh karena itu secara prinsip negara harus mengakui TNCs sebagai subjek hukum internasional, namun demikian mungkin akan sulit bagi negara untuk mengakui mereka sebagai subjek hukum internasional, karena mereka akan merupakan rival bagi negara. Akan tetapi bagi hukum internasional untuk bereaksi terhadap keberadaan TNCs dalam hal peranannya yang begitu besar dalam globalisasi ekonomi, maka sangat diperlukan untuk membebankan kepada TNCs hak dan kewajiban.

Pemain-pemain baru dalam Hukum Internasional, sepeŕti TNCs, Organisasi Internasional, Non-Governmental Organization, telah menyebabkan kedaulatan negara menjadi semakin pluralistik dan terbatas. Walupun demikian, negara akan tetap menjadi pemain utama dalam hukum internasional, namun negara tidak lagi menjadi pemegang

\footnotetext{
${ }^{29}$ lbid.

${ }^{30}$ Martin Dixon, op.ciitt, hlm. 104-106.
} 
monopoli terhadap objek hukum Internasional.

Bagi TNCs untuk memiliki personalitas hukum penuh yang sejajar dengan negara tidaklah perlu. Sebagaimana $/ C J$ berargumen dalam Reparation Case, bahwa subjek hukum internasional tidaklah harus identik dalam sifatnya, termasuk juga dalam hal hak-haknya, sehingga sifat atau karakteristik mereka tergantung kepada kebutuhan komunitas internasional.

Dalam hal ini sudah cukup jika TNCs memiliki hak dan kewajiban yang terbatas dalam hukum internasional, seperti kemampuan untuk menuntut dan kemampuan untuk dituntut, kemampuan untuk-menerima hak-hak dalam hukum internasional dan menanggung kewajiban dalam forum peradilan intemasional, tetapi tidak memiliki kedudukan sebagai anggota dalam forum antara wakil pemerintah dan dalam instrumen internasional seperti Keanggotaan dalam Perjanjian Intemasional, atau Organisasi Internasional. Hal ini bukan saja akan menciptakan suatu fondasi bagi pembentukan rezim tentang pertanggungjawaban langsung TNCs dalam kasus hak asasi manusia dalam hukum internasional, akan tetapi juga masih menempatkan negara sebagai pemain utama dalam hukum internasional.

Dalam hal kapasitasnya sebagai pemegang status hukum dalam hukum internasional akan menyebabkan $T N C s$ dibebani hak dan kewajiban berdasarkan hukum internasional. Ada beberapa banyak bukti yang menyatakan bahwa TNCS memiliki hak dan kewajiban dalam hukum intermasional, dengan menghormati hak-haknya, maka akan juga diterapkan kewajibankewajibannya.

Secara tradisional TNCs diberi hak dalam hukum Investasi Asing, terutama berkaitan dengan masalah pengambilalihan (ekspropriation), kompensasi dan perlakuan yang tidak diskriminatif terhadap TNCs berkaitan dengan perlakuan terhadap perusahaan internasional. ${ }^{31}$ Dalam beberapa Perjanjian Internasional Multilateral TNCs juga memiliki kewajiban langsung. Seperti misalnya, baik dalam International convention on Civil Liability for Oil Pollution Damage dan Convention on Civil Liability for Damage Re- . sulting from Activities Dangerous to the Environment secara langsung memberikan tanggung jawab langsung kepada individu termasuk badan hukum.?

Norma yang dikeluarkan oleh PBB dalam Responsibility of Transnational Corporation and Other Enterprises with Regard to Human Rights Norm tidak hanya mengikat negara tetapi juga menempatkan kewajiban kepada perusahaan Transnasional dan pelaku-pelaku bisnis lainnya. Namun demikian norma tersebut tidak jelas, bagaimana perusahaan Transnasional ini harus secara langsung harus bertanggung jawab. Oleh karena itu, pada saat sekarang ini yang dapat dilakukan ialah adanya tanggung jawab tidak langsung dari TNCs melalui tanggung jawab negara. Dimana tanggung jawab tersebut memang ditujukan kepada negara.

${ }^{31}$ U.N Conference on Trade and Development, The Social Responsibility of Transnational Corporations, U.N. Doc. UNCTAD/ITE/IT/Misc.21 (1999). Diakses dari http:// www.unctad.org/en/docs/poiteiitm 21.en.pdf. diakses tanggal 20 Maret 2006.

${ }^{32}$ Convention on Civil Liability for Oil Pollution Damage, 1969. 
Wartini. Tanggung Jawab TNCs Terhadap Pelanggaran...

\section{b. Soft-Law yang Diterapkan kepada TNCs terhadap Pelanggaran Hak Asasi Manusia dan Perlindungan Lingkungan}

TNCs juga mampu memaksakan hakhaknya. Misalnya dalam suatu perjanjian internasional dalam kerangka Bank Dunia Perusahaan dapat mengajukan perkara ke. Arbitrase Internasional dalam hal investasi di International Center for Settlement of Investment Disputes. Sedangkan dalam kerangka NAFTA, TNCs berhak untuk memperoleh kompensasi dari pemerintah asing kalau pemerintah tersebut melanggar hak-hak TNCs, ataupun dalam hal perdagangan internasional yang melewati batas-batas negara, maka TNCs ini dapat membuat perjanjian penyelesaian sengketa melalui mekanisme penyelesaian sengketa privat (private dispute settlement mechanism). ${ }^{33}$

Selain itu, beberapa tribunal juga mengijinkan TNCs untuk melaksanakan tuntutannya, termasuk The Seabed Dispute Chamber dsb. Oleh karena itu, berdasarkan penelitian yang singkat memperjelas kemungkinan untuk menempatkan TNCs sebagai legal personality dalam hukum internasional dalam menerima kewajiban sebagaimana TNCs melaksanakan hakhaknya.

Sejak tahun 1970an Beberapa Organisasi Internasional telah memformulasikan guidelines, code of conduct, deklarasi dalam rangka untuk mengatur kegiatan TNCs. Dalam hal ini termasuk The Organization of Economic Cooperation and Development (OECD) and the International Labor Organization (ILO). Walupun Guidelines ini tidak secara langsung diterapkan pada TNCs, tetapi negara memiliki tugas untuk menerapkan kewajiban tersebut terhadap TNCs yang berada di wilayah jurisdiksinya. The OECD dan ILO instrumen hanya merupakan pedoman yang berisi mekanisme khususnya untuk menerapkan kewajiban kepada TNCs.

Guidelines OECD tahun 1976 untuk Multinasional Enterprises yang sudah direvisi pada tahun 2000 merekomendasikan sebagai berikut; "respect the human rights of those affected by their activities consistent with the host government's intermational obligation and com$m$ itments ".34 Guidelines ini khususnya merekomendasikan partisipasi TNCs untuk menghilangkan diskriminasi, dan juga untuk tidak mempekerjakan buruh anak dan atau buruh paksa. ${ }^{35}$

Sedangkan dalam Tripartite Declaration of Principles Conceming Multinational Enterprises and Social Policy ditujukan kepada pemerintah negara peserta, pekerja organisasi internasional dan pekerja pada perusahaan termasuk juga TNCs yang beroperasi di negaranya untuk melakukan pertanggungjawaban sosial. ${ }^{36}$ Deklarasi ini mendorong negara untuk menghormati Universal Declaration of Human Rights beserta Covenan-Covenan Internasional relefan lainnya termasuk juga hak-hak dasar buruh.

\footnotetext{
${ }^{33}$ David Kinley and junko Tadaki, op.cit., hlm. 9.

${ }^{34}$ OECD Guidelines for Multinational Enterprises.

${ }^{35}$ Pasal 1 Abolition of Forced Labour Convention 1957.

${ }^{36}$ Richard A. Posner and Kenneth E. Scott, Economic of Corporation Law and Securities Regulation, Toronto, Little Brown and company, 1980,him.69-73.
} 
Dari perspektif pelanggaran hak asasi manusia oleh $T N C s$, maka implementasi dari guidelines OECD maupun ILO tidaklah efektif baik bagi negara maupun bagi TNCs, karena gudelines tersebut sifatnya tidak mengikat dan badan pengawasnya tidak berfungsi sebagai badan quasi peradilan, akan tetapi peran badan tersebut hanya terbatas pada penginterpretasian instrumen. Badan ini tidak menemukan suatu penemuan khusus tentang aktivitas TNCs yang misconduct, dan kalaupun badan ini menemukannya maka hal tersebut akan dirahasiakan. Sehingga TNCs terhindar dari kecaman publik dan rasa malu. Lebih lanjut lagi, jika guidelines dan Deklarasi mendesak TNCs untuk menghormati normanorma hukum hak asasi internasional yang telah diakui oleh masyarakat internasional, maka TNCs ini akan mengutamakan ketentuan hukum nasional dimana TNCs ini beroperasi. Sehingga guidelines ini tidak memiliki kekuatan untuk mencegah host state melanggar hak buruh dan standar lingkungan, dan TNCs tidak dapat dipersalahkan karena mengambil keuntungan tersebut.

Sedangkan The United Nations Global Compact merupakan jenis soft- law lain sebagai instrumen untuk mendorong TNCs tidak melanggar Hak Asasi Manusia dan perlindungan lingkungan. Walupun Global Compact ini tidak sekuat Code of Conduct, akan tetapi tujuannya adalah untuk menghilangkan dan merekomendasikan 9 prinsip dasar yang berkaitan dengan penghormatan hak asasi manusia, hak buruh, dan perlindungan lingkungan, baik melalui praktek-praktek pribadi perusahaan yang didukung oleh kebijakan publik pemerintah. ${ }^{37}$ Namun demikian, sekali lagi dengan kurangnya pengawasan yang independent dan penegakan melalui penjatuhan sanksi menyebabkan kurangnya ambisi untuk melaksanakan prinsip tersebut, ${ }^{-}$sehingga ini berimbas kepada pelanggaran hak asasi manusia dan lingkungan. Global Compact inipun juga tidak dapat berlaku efektif.

Dengan meninjau Instrumen soft-law dari OECD, ILO maupun United Nations Global Compact, dapat disimpulkan bahwa-ketiga instrumen tersebut dalam praktik tidak dapat efektif hal ini disebabkan karena karakter/ sifatnya yang tidak mengikat dan kurangnya mekanisme penerapan yang berarti. Akan tetapi, hal ini telah menunjukkan adanya suatu keinginan beberapa lembaga international untuk memformulasikan beberapa standar hak asasi manusia yang dilakukan oleh TNCs dapat ditindak. Lebih jauh lagi beberapa komentator berpendapat bahwa adanya kemungkinan soft -law ini akan berubah menjadi hard -law melalui pembentukan hukum kebiasaan internasional. Akan tetapi, penerapan yang lemah dari guidelines $O E C D$ dikarenakan tidak konsistennya praktik negaranegara dan tidak adanya pengakuan guidelines tersebut sebagai hukum (opinio juris) untuk membentuk hukum kebiasaan. Oleh karena itu walaupun ini akan ditransformasikan menjadi hard-law di masa depan, guidelines ini belum menyediakan sumber otoritas kewajiban internasional TNCs. Posisi ini sama dengan ILO Declaration dan bahkan Global Compact lebih lemah lagi dibandingkan Guidlines.

${ }^{37}$ David Kinley dan Junko Tadaki, op.cit., hlm.11. 


\section{c. Dampak dari Soft Law}

Berbagai macam bentuk ketentuan yang tidak mengikat sebagaimana disebutkan sebelumnya, telah mempengaruhi dalam pembentukan ketentuan hak asasi manusia bagi TNCs. Adapun dampak soft-law akan dikualifikasikan sebagai berikut: Pertama.Corporate code of Conduct. Karakter/sifat dari Corporate Social Responsobolity (CSR) ${ }^{38}$ Pada masa sekarang ini mungkin akan susah menemukan sebuah TNCs yang tidak mencantumkan kesediaan mereka terhadap suatu code of conduct, setidak-tidaknya berkaitan dengan standar hak asasi manusia.

Tuntutan yang paling menonjol terhadap TNCs untuk bertanggung jawab terhadap pelanggaran hak asasi manusia dan lingkungan diprakarsai oleh NGO, kelompok sosial dan kelompok konsumen di negara maju. Tanggapan tradisional dari perusahaan menyatakan bahwa masalah hak asasi manusia merupakan tanggung jawab negara dan organisasi internasional seperti PBB, dan bukan pemain swasta seperti perusahaan.

Pertanggungjawaban perusahaan (TNCs) terletak pada pemegang saham, yang bertujuan untuk memperoleh suatu keuntungan yang maksimal. Namun demikian, ada suatu tandatanda dimana TNCs mulai berpikir kembali terhadap tindakan dan kebijakan yang dilakukan berkaitan dengan pengaruhnya terhadap kehidupan keberlangsungan business dan prestise TNCs. Sehingga tindakan mereka ini akan memiliki dampak negatif, yaitu menimbulkan image yang negatif dari konsumen, sedangkan dari sisi yang positif
TNCs yang menghormati hak asasi manusia tidak hanya akan meningkatkan prestise, akan tetapi juga akan memberikan kontribusi terhadap kestabilan peraturan dan politik di negara penerima modal (host state) dan akan menyebabkan lancarnya operasional business TNCs serta lebih menguntungkan.

Faktor-faktor tersebut telah mendorong TNCs untuk membuat Code of Conductnya sendiri yang memuat tentang penghormatan terhadap hak asasi manusia dan perlindungan lingkungan. Isi Code of Conduct bermacammacam, ada yang detail', singkat, dan ada juga yang berupa guidelines yang komprehensif. Beberapa Codes bahkan sangat mendukung instrumen hak asasi manusia, seperti Rio Tinto's Code berpedoman pada UDHR dan menyatakan bahwa : "the Rio Tinto Group seeks to have international standar upheld and to avoid situations that could be intepretated as condoning human rights abuses." ${ }^{39}$

Keberadaan Code of Conduct perusahaan ini menimbulkan suatu perdebatan dalam rangka untuk memerangi pelanggaran hak asasi manusia dan hak lingkungan. Apakah code of conduct ini hanya merupakan lip service saja, atau memang benar-benar TNCs membuat suatu langkah nyata untuk mengakhiri pelanggaran hak asasi manusia dan pelanggaran lingkungan?

Lepas dari banyaknya perdebatan tentang Code of Conduct, namun dengan karakteristiknya yang bersiat sukarela, self-regulatory nature dan sifatnya untuk memberikan tekanan yang berarti kepada TNCs. Selain itu Code of Conduct ini berperan memberikan sumbangan terhadap pembentukan norma hukum yang

\footnotetext{
${ }^{36}$ David Kinley dan Junko Tadaki, op.cit., hlm.12.

${ }^{39}$ Rio Tinto, The Way We Work : Our Statement of Business Practice, 9 (April 2003).
} 
diakui ${ }^{40}$ quasi binding dan suatu saat mungkin akan berinkamasi menjadi hukum yang mengikat dan bahkan akan membentuk hukum kebiasaan internasional asalkan didukung oleh praktik negara-negara dan diakui sebagai hukum (opinion juris sive necessitates ).

\section{Dampak Hukum Code of Conduct}

Merujuk kepada pendapat Haim Ward, setidak-tidaknya ada tiga instrumen yang memungkinkan voluntary code berubah jadi hukum yang mengikat. Pertama, Code dalam bidang industri dapat membentuk standar kehati-hatian yang merupakan harapan dalam dunia usaha yang berkaitan dengan para pekerja, pemasok, masyarakat lokal dan pemerintah yang disatukan dalam kontrak yag dilakukan dengan pekerja, pemasok maupun pemerintah. Misalnya saja, A South African Diamond Industry Code yang memuat conflict Diamond mengikutkan juga tentang. approval dari Peradilan Amerika. Selain itu, Perjanjian kontraktual antara TNCs dengan pekerjanya yang didasarkan pada ketentuaan Code of Conduct juga akan menimbulkan akibat hukum.

Kedua, Standar yang dinyatakan dalam Code dapat diadopsi oleh pembuat peraturan yang didasarkan pada adanya kewajiban untuk membuat laporan, dan berdasarkan laporan ini kalau terjadi pelanggaran Code maka pemerintah host state berwenang menegakkan melalui kekuasaan yang dimilikinya, sehingga secara tidak langsung Code tersebut menjadi mengikat TNCs. Seperti misalnya yang terjadi di Inggris, Australia, Belgia dan Jerman. ${ }^{41}$ Negara-negara tersebut mewajibkan perusahaan untuk memberikan informasi terbuka yang dituangkan dalam laporan tahunan segala kegiatan yang dilakukan perusahaan selain masalah keuangan hal ini sesuai dengan ketentuan dalam Global Reporting Initiative Sustainability Reporting Guidelines.

Ketiga, statemen yang dibuat oleh perusahaan dapat dijadikan landasan hukum kalau perusahaan melakukan tindakan yang melanggar Code of conduct. Dalam kasus Kasky v. -Nike dapat dijadikan illustrasi bagaimana code perusahaan ini dapat digunakan dalam kasus seperti ini. Dalam statemen Nike kepada masyarakat umum menyatakan bahwa perusahaan ini akan memberikan perlakuan yang baik kepada para pekerja di Pabrik-pabriknya yang berada di Asean. Kasus ini diselesaikan pada bulan September 2003, dasar landasan Supreme Court California untuk memutus bahwa Nike bersalah ialah Unfair competion Law, karena pernyataan yang dikeluarkan Nike adalah Pernyataan komersial (Comercial Speech). ${ }^{42}$

\section{Dampak Normatif Code of Conduct}

Selain kurangnya dukunga Code sebagai hukum yang mengikat, namun Code memiliki kemampuan untuk membentuk norma yang memiliki effect terhadap perilaku perusahaan dan peraturan hukum dimasa yang akan datang. Sudah disebutkan sebelumnya, bahwa pembentukan Code akan dapat him.26.

${ }^{40}$ Mark E. Villiger, Customary Intemational Law and Treaties, (Boston, Martinus Nijhoff Publishers, 1985),

${ }^{41}$ David Kinley dan Junko Tadaki, op.cit., hlm.14.

${ }^{42}$ Ibid. 
diarahkan untuk pembentukan standar norma baru kepada TNCs. Pandangan seperti ini diberikan oleh argument Bottom-up dari hukum internasional, dimana perilaku negara itu mungkin akan terbentuk karena adanya hubungan negara dengan perusahaan baik nasional maupun Transnasional.

Berdasarkan analisis ini norma informal social yang dibuat dan diterapkan pada perusahaan berkemampuan untuk membentuk perilaku negara, dan bahkan kepada perilaku hubungan negara dengan institusi yang lain. Sebagai akibatnya dapat ditarik suatu kesimpulan bahwa pembentukan standar hukum didasarkan pada kecenderungan perilaku sosial yang diintsruksikan dari standar hukum.

Jika TNCs secara konsekuen menerapkan perlindungan hak asasi manusia melaui pasar, maka nilai-nilai domestik juga akan mendukung penerapan nilai-nilai tersebut. Jika diasumsikan bahwa hukum nasional mendukung penerapan nilai-nilai hak asasi manusia maka akan dibutuhkan adanya dukungan dari badan legislatif, eksekutif dan yudikatif. Jika standar tersebut diterapkan dalam hukum nasional suatu negara, maka akan terjadi tekanan kolektif untuk menerapkannya di level internasional. Dengan jalan separate ini merupakan suatu cara pembentukan hukum internasional melalui hukum nasional publik dan privat.

Perkembangan yang paling signifikan dalam hal ini ialah pembentukan norma hak asasi manusia bagi TNCs oleh PBB yaitu dengan memindahkan tanggung jawab jaminan hak asasi manusia dari negara kepada TNCs, walaupun pelaksanaannya masih jauh dari harapan, namun tindakan seperti ini memberikan dampak terhadap perilaku perusahaan. Dari apa yang sudah dijelaskan sebelumnya, maka dapat disimpulkan dampak soff-law dalam penerapan tanggung jawab TNCs terhadap pelanggran hak asasi manusia dan lingkungan masih bersifat potensial dari pada pembentukan perilaku TNCs.

Sedangkan kalau diAmerika Serikat dalam rangka untuk menjerat perilaku TNCs yang melanggar hak asasi manusia maupun perlindungan lingkungan yang dilakukan di laur Amerika yaitu dengan menerapkan Alian Tort Claim Act (ATCA) Amerika secara extra territorial. ${ }^{43}$ Akibatnya sudah beberapa kasus berhasil diputuskan oleh Pengadilan Amerika, baik kasus pelanggaran hak asasi manusia maupun pelanggaran perlindungan lingkungan yang dilakuakn oleh negara maupun TNCs.

Dampak potensial seperti ini memberikan suatu rintisan yang berarti dalam pembentukan perilaku perusahaan. Apa yang dapat dipelajari dari dampak soft-law ialah bahwa setiap komponen hukum maupun bukan hukum memeliki peranannya masing-masing dan saling terkait antara satu dan lainnya. Tinggal bagaimana mensolitkan perubahan code of conduct dari soft-law menjadi hard-law merupakan suatu movemen yang yang signifikan.

${ }^{43}$ Anastasia Khokhryakova, " Beanal V. Freeport-McMoran,Inc: Liability of Private Actor For an international Environmental Tort Under The Alien Tort Claims Act", Colorado joumal of Intemational Environmental Law and policy, Vol 9, Summer 1998, him.1-4. 
Tanggung Jawab Hak Asasi Manusia TNCs terhadap Pelanggaran Hak Asasi Manusia dan Lingkungan

- Tanpa mengingkari adanya perkembangan peranan Code of Conduct dalam masyarakat internasional, temyata masih meninggalkan dua pertanyaan yang mendasar yaitu bagaimana memunculkan tanggung jawab TNCs dan kewajiban apa yang seharusnya diemban oleh TNCS. Walaupun beberapa TNCS lebih powerful dari pada negara namun tidaklah begitu mudah untuk membebankan kewajiban hak asasi yang sama antara perusahaan dan negara. Sebagai perusahaan swasta TNCs bertujuan dan didesain untuk mencari keuntungan bukan untuk mensejahterakan rakyat. Dengan alasan untuk menghormati hak asasi manusia oleh TNCs maka harus diabaikan tentang perbedaan sifat I nature antara negara dan korporasi.

Perbedaan yang signifikan antara TNCs dan negara antara lain adalah masalah Jurisdiksi. Berdasarkan hukum internasional negara memiliki kewajiban untuk melindungi hak asasi manusia kepada siapa saja yang berada di wilayah negaranya, untuk memenuhi kewajiban internasionalnya. Dalam hal TNCs apakah dapat dianalogikan dengan negara? Sampai sejauhmana TNCs harus bertanggung jawab terhadap pelanggaran hak asasi manusia dan pelanggaran lingkungan yang dilakukan oleh anak perusahaannya, agen supplier dan pembeli ? Tidaklah mudah untuk menjawab pertanyaan ini.

Oleh karena TNCs belum diakui sebagai subjek hukum intemasional, maka kewajiban internasional TNCs untuk melindungi hak asasi manusia tidaklah seluas yang dimiliki oleh negara. Namun demikian bukan juga berarti sangat minim atau tidak ada. Beberapa norma hak asasi manusia ada yang dapat diterapkan secara langsung, akan tetapi ada beberapa yang harus diformulasikan kembali sesuai dengan sifaf TNCs. TNCs adalah yang beroperasi di masyarakat internasional. Sebagai subjek hukum privat, TNCs memiliki hak-hak hukum, termasuk dalam situasi tertentu perlindungan akan hak asasi manusia. Kedudukan ini sangat lain dengan negara dimana negara berkedudukan sebagai pelindung hak asasi manusia.

Berkaitan dengan masalah pelanggaran hak asasi manusia dan- masalah kerusakan lingkungan yang dilakukan oleh TNCs beserta akibatnya terhadap manusia dan lingkungan merupakan permasalahan internasional yang sangat urgen untuk segera ditangani.

\section{Simpulan}

Berdasarkan uraian tersebut di atas maka dapat disimpulkan hal-hak sebagai berikut, hubungan antara lingkungan yang sehat dan hak asasi manusia sangatlah erat. Dapat dikatakan bahwa perusakan lingkungan sebagai salah satu bentuk pelanggaran lingkungan juga merupakan pelanggaran hak asasi manusia. Hukum Hak Asasi Manusia Internasional dan Hukum lingkungan Internasional belum mampu untuk melindungi secara efektif atas pelanggran hak asasi manusia maupun pelanggaran perlindungan lingkungan yang dilakukan oleh TNCs, karena TNCs belum merupakan subyek hukum internasional, sekalipun sudah ada beberapa keputusan Pengadilan yang menjatuhkan sanksi pada TNCS. Pembentukan dan pemberlakuan soft-law seperti code of conduct, global compact dan guidelines OECD maupun ILO bagi TNCs diharapkan akan dapat mempengaruhi perilaku 
TNCs dan dimasa depan diharapkan soft-law ini dapat berubah menjadi hard-law yang mengikat TNCS.

\section{Daftar_Pustaka}

Akehurst, Michael AModem Introduction to International Law, fourth Edition, London, George Allen and UNWIn limited, 1982.

A. Sonny Keraf, Etika Lingkungan, Jakarta, - Kompas, 2002.

Boer Mauna, Hukum Internasional Pengertian, Peranan dan Fungsi Dalam Era Dinamika Global, Bandung, Alumni, 2000.

Brown Weiss Edith, "Intergenerational Equity: A legal Framework for Global Environmental Change ", dalam Environmental Change and International Law, United Nations, Tokyo University Press, 1992.

Esty C. Daniel, Greening the GATT, Trade, Environment, and the Future, London, Longman Group, UK limited, 1994.

Dixon Martin, Public International law, Fourth Edition, United Kingdom, Bkackstone Press Limited.

Boyle E. Alan and Michael R. Anderson, Human Rights Approachs to Environmental Protection, New York, Oxford University Press, 1996.

K.M. Smith Rhona, International Human Rights Law, Second Edition, Oxford University Press, New York, 2005.

Posner Richard A. and Kenneth E. Scott, Economic of Corporation Law and Securities Regulation, Toronto, Little Brown and company, 1980.

Schijver Nico, Souveregnty over Naturaral Resources, Cambridge University
Press, New York, 1997.

Sands Philippe, Principles of International Environmental Law, New York, Manchester University Press, 1995.

UN Conference on Trade and Development, The Social Responsibility -of Transnational Corporations, U.N. Doc. UNCTAD/ITE/IIT/Misc.21 (1999). Diakses dari http:// www.unctad.org/en/ docs/poiteiitm 21.en.pdf. diakses tanggal 20 Maret 2006.

WTO Secretariat, Trade Development and the Environment, London, Kluwer Law International, 2000.

Kinley David dan Junko Tadaki, "From Talk to Walk: The Emergence of Human Rights Responsibility for Corporation at unternational Law, Virginia Journal of International Law, Summer 2004.

Khokhryakova Anastasia, "Beanal V. FreeportMcMoran, Inc : Liability of Private Actor For an International Environmental Tort Under The Alien Tort Claims Act", Colorado journal of International Environmental Law and policy, Vol 9, Summer 1998.

Lindsay Shinsato Alison, "Increasing The Accountability of Transnational Corporations for Environmental Harms : The Petrolium Industri in Nigeria", 4 Northwestern University Journal of Internatioanl Human Rights, December 2005.

M. Schmidt Tracy, " Transnational Corporate Responsibility for International Environmental And Human Rights Violations : Will the Unitted Nations "Norms " Provide The required Means ? ", California Westerm Law Journal, Vol.36, Fall 2005. 
Mowery A.- Lauren, " Earth Rights, Human Rights : Can Environmental Human Rights Affect Corporate accountability ?", Fordham Environmental Law journal,Vol.13, Spring, 2002.

Convention on Civil Liability for Oil Pollution Damage, 1969.

Rio Declaration

Stockholm Declaration niversal Declaration of Human Rights http://id.wikipedia.org/wiki/Freeport_Indonesia. diakses pada tanggal 20 Maret 2006.

http://dte.gn.apc.org/AF16.htm, " IFls in Indo- nesia "diakses tanggal 17 Maret 2006. http://www.men/h.go.id/terbaru/ artikel.php? article-id $+170 \&$ PHPSESSID=b9ccf4801728..., diakses pada tanggal 18 Maret 2006. http://id.wikipedia.org/wiki/Freeport-Indonesia, diakses pada tanggal 18 Maret, 2006. http :/l www.unhcr.ch/business.htm, diakses tanggal 20 Maret 2006. United Nations High Commissioner for Human Rights, Business And Human Rights : A Progress Report ( Jan. 2000). 